\title{
Management of Striga (Striga hermonthica) in Sorghum (Sorghum bicolor L.) in Jeldu District
}

\author{
Shashitu Bedada Desalengn Gela Nigussie Hundesa Gectachew Bekele Tesfaye Abdisa \\ Dereje Geremew Tadele Gudeta \\ EIAR, Ambo Agricultural Research Center. P. O. Box 37. Ambo, Ethiopia
}

\begin{abstract}
A field experiment was conducted from 2017 to 2018 to determine the chemical herbicides which can best perform against Striga in sorghum fields of Jeldu district, West Shoa Zone. The experiment was carried out in randomized complete block design with three replications. Result obtained indicted that, sorghum plant height, stock biomass, grain yield and thousand seed weight showed significantly different $(\mathrm{P}<0.05)$ among treatments. The highest mean plant height $(240.92 \mathrm{~cm})$, stock biomass $(13967 \mathrm{~kg} / \mathrm{ha})$, grain yield $(886.2 \mathrm{~kg} / \mathrm{ha})$ and thousand seed weight $(24.3$ g) were recorded from the sequential application of Metalachlor $960 \mathrm{EC}+2,4-\mathrm{D}$ as compared to weedy check. The lowest Striga height $(31.917 \mathrm{~cm})$ was recorded from sequential application of Metalachlor $960 \mathrm{EC}+2,4-\mathrm{D}$. Similarly the lowest Striga biomass were recorded from farmers practice followed by kerosene (for seed dressing) and sequential application of Metalachlor $960 \mathrm{EC}+2$, 4-D. Therefore, sequential application of Metalachlor 960 $\mathrm{EC}+2,4-\mathrm{D}$ is recommended as one component of integrated Striga management in sorghum field.
\end{abstract}

Keywords: Sorghum bicolor L, Striga hermonthica, Dual gold and 2, 4-D

DOI: $10.7176 / \mathrm{JBAH} / 10-16-03$

Publication date:August $31^{\text {st }} 2020$

\section{Introduction}

Ethiopia is the home of origin for sorghum varieties cultivated worldwide. Sorghum is one the most important cereal in the world, only exceeded by wheat and rice as staple food in the tropics and raw materials for many industrial products in Ethiopia.

Striga hermonthica that belongs to Orobanchaceae family is one of the cereal crops root parasite often causing $30-100 \%$ crop losses on farmers' fields throughout the world (Ouedraogo, 1992). It is an important biotic constraint to sorghum and maize crop production, and the weed that farmers fear the most (Ramaiah, 1985). Striga species threaten the lives of over 100 million people in Africa and it infest about $40 \%$ of arable land in the Savannah region arable land causing a loss of US\$ 7 to 13 million. Similarly, As Baguma and Bigirwa (1996) estimated an economic loss of US\$ 8 million a year.

The herbicidal control of Striga prior to flowering and seed set can contribute to reduction of the soil seed bank and subsequent Striga infestation. However, chemical control of striga is not widely practiced due to its high cost and the need for specialized equipment, unavailability on market, and environmental concerns by the public at large. In northern Cameron and Nigeria 2.4-D and triclopyr, Dual Gold (Metalachlor 960 EC), and Primagram have been applied at a dose of and $1 \mathrm{l} /$ ha and $3 \mathrm{lt} \mathrm{ha}^{-1}$, respectively. These herbicides reduced the number of striga emerged and increased sorghum yield (Carsky et al., 1994; Lagoke et al., 1994). However, Carson (1993) reported that 2.4-D was inefficient chemical for controlling the parasite in maize in Gambia. Thus, this experiment was designed to evaluate chemical herbicides which can best perform against Striga in sorghum fields of West Shoa Zone districts.

\section{Material and Methods}

The evaluation work was conducted in Jeldu, District of West Shoa Zone on naturally striga infested sorghum field. The experiment was laid out using RCBD with three replications. Treatments were application 2, 4-D on $85^{\text {th }}$ days after sowing, primgram at 3 lt/ha, Dual Gold (Metalachlor 960 EC) at 3 1/ha; 2.4-D at lt/ha + Primagram at 3 lt/ ha; 2.4-D at lt/ha + Metalachlor $960 \mathrm{EC}$ at 3 lt/ha, Kerosene (for seed dressing), farmer practice and weedy check. Post emergence herbicide, 2.4-D application was made on 85th day after sowing and pre-emergence herbicide Metalachlor 960 EC and Primgram was applied 1 day after sowing. Improved variety of sorghum "Alemaya ETS-2752" was used as test crop. The size of each plot was $6 \mathrm{~m} \times 5 \mathrm{~m}$ with a distance of $1 \mathrm{~m}$ between plots and $1.5 \mathrm{~m}$ between block were left to avoid spray drift from adjacent plot.

\section{Data collection}

Data on yield and yield component of Sorghum such as: Sorghum plant count, plant height, stock biomass, grain yield and 1000 seed weight were recorded. In addition to that data on Striga plant count per plot, Striga plant height, and biomass were collected. Analysis of variance was done using appropriate computer software. 


\section{Results and Discussion}

\section{Effect of herbicides on yield and yield components of Sorghum}

Sorghum plant height, stock biomass, grain yield and thousand seed weight showed significant difference $(\mathrm{P}<0.05)$ due to herbicides (Table1). The highest mean plant height, stock biomass and grain yield were recorded from the sequential application of Metalachlor $960 \mathrm{EC}+2,4-\mathrm{D}$ as compared to weedy check. The highest thousand seed weight was also recorded from sequential application of Metalachlor 960 EC + 2, 4-D and 2, 4-D application. Therefore, Sequential application of Metalachlor $960 \mathrm{EC}+2,4-\mathrm{D}$ was effective in increasing plant height, crop biomass and grain yield as compared to other treatments. However, Sorghum plant population showed nonsignificant due to herbicide treatment (Table 1).

\section{Effect of herbicides on Striga population, height and biomass}

Striga population and biomass showed non-significant difference among treatments though, the highest Striga population (16333 plants/ha) was observed from the application of 2, 4-D followed by sequential application of Metalachlor 960 EC + 2, 4-D. Striga plant height showed significant difference $(\mathrm{P}<0.05)$ due to herbicides (Table2). The lowest Striga plant height $(31.917 \mathrm{~cm})$ was recorded from sequential application of Metalachlor 960 EC + 2, 4-D. Similarly, the lowest Striga population and biomass were recorded from sequential application of Metalachlor $960 \mathrm{EC}+2$, 4-D though there was no significant differences among the treatments. Therefore, sequential application of Metalachlor $960 \mathrm{EC}+2$, 4-D was reduced Striga height population and biomass as compared to other treatments.

Table1. Effect of herbicides on Sorghum plant height, population density, biomass, thousand seed weight and grain yield in Jeldu district during 2017/2018

\begin{tabular}{|c|c|c|c|c|c|}
\hline Treatments & $\begin{array}{l}\text { Plant height } \\
\text { (cm) }\end{array}$ & $\begin{array}{l}\text { Plant } \\
\text { population } / \mathrm{ha}\end{array}$ & $\begin{array}{l}\text { Stock biomass } \\
(\mathrm{kg} / \mathrm{ha})\end{array}$ & $\begin{array}{l}\text { Grain } \\
(\mathrm{kg} / \mathrm{ha})\end{array}$ & $\begin{array}{l}1000 \text { seed } \\
\text { weight }(\mathrm{g})\end{array}$ \\
\hline Year 2017 & $236.083^{a}$ & $29817^{b}$ & 11067 & $716.8^{a}$ & $24.2167^{\mathrm{a}}$ \\
\hline Year 2018 & $209.042^{b}$ & $66967^{\mathrm{a}}$ & 9518 & $473.5^{b}$ & $22.5125^{b}$ \\
\hline LSD & 13.787 & 6138.8 & ns & 204.55 & 1.2547 \\
\hline $2,4-\mathrm{D}$ & $225.08^{a b}$ & 48000 & $12800^{a b}$ & $666.6^{\mathrm{ab}}$ & $24.383^{\mathrm{a}}$ \\
\hline Primgram & $228.58^{a b}$ & 50200 & $9933^{a b c}$ & $564.3^{\mathrm{ab}}$ & $23.950^{\mathrm{ab}}$ \\
\hline Metalachlor $960 \mathrm{EC}$ & $217.50^{\mathrm{ab}}$ & 47533 & $7967^{b c}$ & $497.2^{a b}$ & $21.617^{b}$ \\
\hline $\begin{array}{l}\text { Metalachlor } 960 \mathrm{EC}+ \\
2,4-\mathrm{D}\end{array}$ & $240.92^{\mathrm{a}}$ & 51000 & $13967^{\mathrm{a}}$ & $886.2^{\mathrm{a}}$ & $24.300^{\mathrm{a}}$ \\
\hline Primagram+2,4-D & $222.67^{\mathrm{ab}}$ & 44067 & $12200^{a b}$ & $609.2^{\mathrm{ab}}$ & $23.583^{\mathrm{ab}}$ \\
\hline $\begin{array}{l}\text { Kerosene (for seed } \\
\text { dressing) }\end{array}$ & $227.67^{\mathrm{ab}}$ & 47667 & $11367^{\mathrm{ab}}$ & $674.8^{a b}$ & $23.933^{a b}$ \\
\hline Farmers practice & $211.75^{b}$ & 50667 & $8140^{b c}$ & $510.4^{a b}$ & $22.833^{a b}$ \\
\hline Un treated & $206.33^{\mathrm{b}}$ & 48000 & $5967^{c}$ & $352.4^{\mathrm{b}}$ & $22.317^{\mathrm{ab}}$ \\
\hline LSD (0.05) & 27.573 & Ns & 4886.5 & 409.11 & 2.5094 \\
\hline $\mathrm{CV} \%$ & 10.50 & 21.517 & 40.26 & 58.3 & 9.108 \\
\hline
\end{tabular}

Note: Means followed by the same letter within a column are not significantly different at $0.05 p ; n s=n o n$ significantly different 
Table2. Effect of different herbicide on Striga plant population and height and biomass in Jaldu district, during $2017 / 2018$

\begin{tabular}{|c|c|c|c|}
\hline Treatments & $\begin{array}{l}\text { Striga population } \\
\text { (Number of plants /ha) }\end{array}$ & $\begin{array}{l}\text { Striga plant height } \\
(\mathrm{cm})\end{array}$ & $\begin{array}{l}\text { Striga biomass } \\
(\mathrm{kg} / \mathrm{ha})\end{array}$ \\
\hline Year 2017 & 23000 & $43.717^{\mathrm{a}}$ & $278^{\mathrm{b}}$ \\
\hline Year 2018 & 29742 & $33.119^{b}$ & $60348^{a}$ \\
\hline LSD & Ns & 3.7304 & 35717 \\
\hline $2,4-\mathrm{D}$ & 16333 & $41.700^{\mathrm{a}}$ & 7833 \\
\hline Primgram & 38333 & $40.694^{\mathrm{a}}$ & 58500 \\
\hline Metalachlor 960 EC & 32000 & $39.856^{\mathrm{a}}$ & 56193 \\
\hline Metalachlor $960 \mathrm{EC}+2,4-\mathrm{D}$ & 10067 & $31.917 \mathrm{~b}$ & 5500 \\
\hline Primagram +2,4-D & 28767 & $38.265^{a b}$ & 30793 \\
\hline Kerosene (for seed dressing) & 18000 & $38.183^{a b}$ & 9767 \\
\hline Farmers practice & 17000 & $39.246^{\mathrm{ab}}$ & 24073 \\
\hline Untreated & 50467 & $37.480^{\mathrm{ab}}$ & 49847 \\
\hline LSD (0.05) & Ns & 7.4608 & ns \\
\hline $\mathrm{CV} \%$ & 130.69 & 16.47 & 199.856 \\
\hline
\end{tabular}

\section{Conclusion and Recommendation}

Significantly highest Sorghum plant height $(240.9 \mathrm{~cm})$ and grain yield $(886.2 \mathrm{~kg} / \mathrm{ha})$ were recorded from sequential application of Metalachlor $960 \mathrm{EC}+2,4-\mathrm{D}$ as compared to un treated check. Similarly, maximum stock sequential application of Metalachlor $960 \mathrm{EC}+2,4-\mathrm{D}$ as compared to other treatments. Similarly, the lowest Striga population, height and biomass were recorded from sequential application of Metalachlor 960 EC +2 , 4-D as compared to other treatments. Therefore, sequential application of Dual gold +2 , 4-D is effective against Striga weed in sorghum. So, sequential application of Metalachlor $960 \mathrm{EC}+2$, 4-D is recommended as one component of integrated Striga management in sorghum fields.

\section{References}

Carsky, R.J.Singh,I.and Nidkawa, R.(1994).Effect of herbicide and hand weeding on current and subsequent season Striga hermonthica, density on sorghum. Internationa Journal of pest management.

Carson, A.G. (1993). Studies on Bio-and Chemical control of Striga hermonthica (Del.) Benth.In the Gamibia.Nuisibles-pests-pragas 1:71-81.

Kim, S.K. (1991). Breeding maize for Striga tolerace and the development of a field infestation technique. pp. 96108. In: S.K. Kim (ed.) Combating Striga in Africa. Proceedings of International Work on Striga, Organized by IITA, ICRISAT and IDRC, Ibadan, Nigeria, 22 - 24 August, 1998.

Lagoke, S.T.O., Shebayan ,J.Y., Weber, G.,.K., Emechebe, A.M., Singh, B.B., Zaria. A.,Awad,A.,Nagawa,L.,Olaniyan,G.O.,Olafare.,S.O.,Adeoti,A.A.and Odion,C.(1994). Survey of striga problem and evaluation of striga control methods and packages in crops in the Nigerian savannah. In improving striga management in Africa ,Proceedings of the $2^{\text {nd }}$ General workshop (PASCON).23-29 June 1991,Nairobi Kenya.Lagoke,S.T.O.,Hoevers,R.M Book .S.S.and Traboulsi,R.(Eds.).pp.91-120.FAO.Accra.

Ouedraogo, O.(1992). Quelques methods detudes du problem du striga au Burikinafaso DESU.Biologie Vegetale tropicale.universite pirre et Marie curie Paris VI.41 pp.

Ramaiah, K.V., Parker, C. (1982). Striga and other weeds in sorghum.In:Sorghum in the Eighties.Vol.I proc.Int.Symp,on Sorghum.2-7 November 1981.ICRISAT,Patancheru,A.P.502 324,India.pp.291-302.

Ramaiah, K.V. (1985).Hand pulling of Striga hermonthica in pearl millet. Tropical pest management 31:326-327. 